ARTICLE

DOI: $10.1057 /$ s41599-017-0053-9

\title{
Intimate constraints: a feminist political economy analysis of biological reproduction and parenting in high-support housing in Ontario
}

Tobin LeBlanc Haley ${ }^{1}$

\begin{abstract}
To date there has been little consideration of the role of housing programs in conditioning the intimate lives of people living with mental illness labels. This article employs a Feminist Political Economy lens with insights from Mad \& Disability Studies to interrogate the intimate constraints experienced by some residents in high-support mental health housing in Ontario, Canada. It demonstrates that long-standing medicalized notions of mental illness and system-wide anxiety over the social and financial costs of the reproduction of disabled bodies give rise to these intimate constraints, specifically limitations and control over biological reproduction and parenting practices. In this way, the mechanisms of intimate constraint within high-support housing are not merely holdovers from a time gone by, but are rather part of a mental health care system guided by the principles of neoliberalism under which neo-eugenics is regularly enacted. This is a timely contribution, as the province of Ontario is currently planning to expand the supportive housing system within which highsupport housing is situated and because high-support housing in Ontario is rarely studied in relation to feminist political economy and/or mental health care. This article draws on documentary review of governmental and third-sector materials and 38 semi-structured interviews with service providers and residents in the high-support housing system in Ontario. It situates intimate constraints within the long history of eugenics and neo-eugenics in Ontario and Canada, and the classed, raced, and gendered hierarchy of human bodies that is taking on new forms under neoliberalism.
\end{abstract}

\footnotetext{
${ }^{1}$ Ryerson University, Toronto, ON, USA. Correspondence and requests for materials should be addressed to T.L.H. (email: tobinh@ryerson.ca)
} 
And alone will I be, here, when death is nigh, having lived for love and loved alone

Fiver, Waltz for One (2017)

\section{Introduction}

Fiver's (2017) folk song, Waltz for One, recovers the history of a young woman institutionalized in Ontario's Rockwood Asylum for the Criminally Insane in the late 1800s. The young woman was institutionalized after becoming pregnant 'out of wedlock' and being forced by her father to have an abortion. The song is a lament about the loss of her lover, child, and their future (Warner). Fiver's voice is raw and the fiddles at times discordant, evoking in this listener anger and sadness about the pathologization, criminalization and institutional control over the bodies of people labelled mentally ill.

The timbre of Waltz for One 'feels' old, but the song is new, recorded using modern equipment and available in MP3, FLAC and ALAC formats (idee fixe records). The use of new technologies of musical production to tell this 'old story' not only recovers the young woman's experience for a contemporary audience, but also serves as a symbol of the morphogenetic history of limitation and control over the intimate lives of people labelled as 'mentally ill' in Ontario. The song draws attention to the current moment.

It is the current moment of limitation and control that I take up in this article, specifically the limitations and control over biological reproduction and parenting sometimes present in Ontario's high-support housing system. High-support housing is one type of supportive housing offered in the province of Ontario. The term 'high-support' indicates that staff members are on site all day or $24 \mathrm{~h}$ each day. High-support housing is also typically a form of congregate living, meaning that residents have their own units (either rooms, occasionally shared, or apartments) but live together in a building, or dedicated wing of a building, for people with psychiatric diagnoses and/or an addictions labels. Suttor (2016), estimates there are approximately 1200 of these units in the province. As part of the larger supportive housing system, the goals of high-support housing include providing 'affordable housing linked to supports' that facilitates community living for people with a wide range of disability labels (Toronto Mental Health and Addictions Supportive Housing Network), but, as this paper demonstrates, affordable housing and community living come with limitations on intimate lives.

In analyzing intimate life in high-support housing in Ontario, I draw on a feminist political economy lens informed by Mad \& Disability studies to argue that long-standing medicalized notions of mental illness and system-wide anxiety over the social and financial costs of the reproduction of disabled bodies give rise to these intimate constraints. In this way, the mechanisms of intimate constraint within high-support housing are not merely holdovers from a time gone by, but are rather part of a mental health care system guided by the principles of neoliberalism under which neo-eugenics is regularly enacted, often through coercive mechanisms arising from structure of housing itself, the rules governing these spaces, the lack of sufficient economic and social supports and intense state scrutiny. Intervening into the arrangement of these spaces is of critical importance. Currently, the province is extending funding to housing providers as a means of growing the supportive housing system within which high-support housing is located. Specifically, funding for up to 1500 new units within supportive housing has been allocated (Ministries of Housing and Municipal Affairs; Government of Ontario, Newsroom, 2017). It is necessary that stakeholders consider how emerging and existing sites can be reorganized to reduce the limitations on and control over the intimate lives of residents.

To analyze intimate constraint in high-support housing, I first provide a more in-depth discussion of the methods and methodology employed in the analysis. Second, I briefly review the history of limitation and control exercised over people labelled mentally ill in the West, with a particular emphasis on the experience of Ontario. Third, I provide a discussion of the precise nature of limitation and control over the biological reproduction and parenting within the homes in Ontario.

I do not mean to suggest that intimate constraints only impact people labelled mentally ill. Many people experience overt and subtle forms of intimate constraints in relation to their class position, gender, racialization, citizenship status and other social constructs. One example is the experience of migrant Live-InCaregivers in Canada, who are often unable to have their children migrate and live with them (Arat-Koc, 2006). Indeed, constraints manifest in numerous contexts to limit who can and cannot reproduce and parent, and this paper aims to add one small piece to this larger puzzle.

It is important to state that I do not intend to sidestep the issue of child welfare and well-being. If a particular environment is unsafe for a child certainly that must be remedied. But as this paper demonstrates, there is no opportunity for residents to even attempt to engage in parenting and there are limitations on biological reproduction.

\section{Methods}

In building this analysis of intimate constrains in high-support housing sites, I draw on archival research, documentary review and 38 semi-structured interviews with residents (23 interviews) and service providers (15 interviews) living and working, respectively, in high-support housing in Ontario. This research was reviewed and approved by the Research Ethics Board at York University in Toronto, Canada. Archival material was collected from the Provincial Archives of Ontario, the City of Toronto Archives and the Centre for Addiction of Mental Health Archives. Archival material analyzed included housing papers and reports, welfare programs, mental health strategies, and consumer/survivor/ex-patient newspapers from the 1980s and the 1990s. The documentary review involved analysis of more contemporary policies, reports and programs from the Ministries of Health and Long-Term Care, Housing, Municipal Affairs and Community and Social Services, Local Health Integration Networks, various non-profit organizations such as the Ontario Non-Profit Housing Association and provincial legislation, including the Residential Tenancies Act (RTA). Access to potential interview participants was organized through housing networks in the province. Interviews were mostly conducted on site in private rooms and residents were provided with a small honorarium for their participation. Staff completed interviews during their work hours. Given the highly sensitive nature of the information collected and the on-going discrimination experienced by people labelled mentally ill, in particular Not-In-My-Back-Yard attitudes and high rates of violence against people with disability labels, I do not name the sites I visited in the interest of protecting the confidentiality of the people interviewed. Nor do I state the specific number of sites I visited as a means of further preserving the confidentiality of the spaces and people interviewed given the small proportion of high-support housing within the wider supportive housing system. I can state that I visited more than one and less than five supportive housing sites in the province of Ontario. I also have, when necessary, altered distinctive patterns of speech, removed all reference to job titles (referring only to people as service providers or staff interchangeably) and removed personal details to ensure no participant is identified. Where quotes have been altered, I have indicated changes using brackets. This level of anonymization of the sites themselves and the participants is necessary to maintain confidentiality.

There are certainly limitations to this study. The sample size is relatively small and I did not visit all high-support housing sites in the province. Therefore, I do not conclude that these intimate constraints manifest in the same ways across highsupport housing or are experienced by all residents. Rather, what I aim to demonstrate is why and how the intimate constraints that I observed manifest and how they are part of a long history of intimate constraint in the lives of people labelled mentally ill.

\section{Methodology}

Feminist political economy. In analyzing the data, I employ a critical political economy lens, drawing in particular on feminist political economy insights into social reproduction under 
neoliberalism. In this paper, neoliberalism is defined as an economic ideology that promotes the penetration of market rule into the economy, the state, and everyday life through political-economic strategies such as the retrenchment and redesign of state supports, the privatization of state assets, and the mobilization of an ideal self-interested, self-reliant individual citizen through public and social policy (Peck and Tickell, 2002; Harvey, 2005; Bezanson and Luxton, 2006a; Wacquant, 2010).

Feminist political economists, intervening into neoliberalism, demonstrate how the focus on market logic in all aspects of life has dramatically altered how the work involved in reproducing people is spread 'across the state-market-family/household-thirdsector nexus' (Bezanson and Luxton, 2006a, b, p. 5; McKeen and Porter, 2003). This work of reproducing people, called social reproduction, is the socially-necessary daily and intergenerational paid and unpaid work of fulfilling bodily, emotional, and social needs. The gendered, raced and classed arrangements of social reproduction maintain and reproduce workers, future workers, and unemployed people, as well as the social order necessary to sustain capitalist society, by using resources acquired through individual labour, state provisions and communities (Bakker, 2003a; Bakker and Gill, 2003b, c; Bezanson and Luxton, 2006a, b; Brodie, 2010).

To put it another way, the organization of the necessary work involved in reproducing people in the day-to-day as well as across generations is directly related to who has access to work, how much they are paid, how secure their employment is and the rate at which governments will intervene to redistribute resources needed for socially reproductive work. It is through the processes of social reproduction that social norms and constructs are embedded in and written on bodies, practices, and places. Highsupport housing is a site of social reproduction; specifically daily maintenance- the day-to-day component of social reproduction (Bakker and Gill, 2003b; Fudge and Vosko, 2003; Vosko, 2006). These homes are spaces where the resources for daily living are provided, albeit at a bare minimum, through the state/market/ family/third-sector nexus, and the work involved in reproducing people in the day-to-day is completed by residents and staff. As this paper demonstrates, these resources are provided, and the work is completed, through highly medicalized arrangements such as disability specific income supports, the presence of clinicalized support workers focused on medication administration, and routinized appointments with medical staff. Through the processes of social reproduction, the biomedical model of mental illness is communicated and legitimized against the backdrop of a mental health care system focused on the independence of service users through 'appropriate' use of the medical system.

Mad \& Disability studies. Identifying and problematizing the interplay between the medical model of mental illness and neoliberal policy-making would not be possible without insights from Mad \& Disability scholars and activists. In this paper, Mad \& Disability scholarship occupies as important a place as feminist political economy. Feminist political economy, while committed to intersectionality as a means of deepening analyses of the organization and operation of capitalist production (see, for example, LeBaron and Roberts, 2010; Steans and Tepe, 2010; Vosko, 2010), has not developed sustained attention to issues of 'mental illness' and Madness. While I seek to extend the scope of feminist political economy further to include questions of mental health, such an attempt will only serve to benefit people labelled as mentally ill if the insights of Mad \& Disability scholars and activists are incorporated into the analytic framework. These 'sibling' fields of scholarship and activism are dedicated to recovering the history and challenging the on-going marginalization of people living with disability labels. Mad Studies, a relatively new scholarly development emerging primarily from the work of people assigned psychiatric diagnoses (Morrow, 2017), critically engages with the mobilization of pathologizing categories by psydisciplines, the state, the market, families, and communities in the oppression of people labelled mentally ill (see, for example, edited volumes by LeFrancois et al., 2013; Russo and Sweeny, 2016; Morrow and Halinka Malcoe, 2017). When considering public mental health care systems, I take seriously critiques of the 'taken for granted' pathologization of people labelled mentally ill (Cohen, 2013), the long history of state oppression underpinned by this pathologization (Simmons, 1990; Reaume, 2009) and the often reciprocal relationship between categories of mental illness and the prevailing arrangement of production (Moncrieff, 2008), in particular the relationship between biomedicalization and neoliberalism (Morrow, 2017).

In recording and analyzing the experiences of people with mental illness labels, and all disability labels, Mad \& Disability Studies scholars have not neglected issues related to intimacy. In fact, the different facets of intimate life-love, sex, birth, death and caring-are of paramount importance to the disability community today as government officials, medical and legal professionals, and Deaf, disabled, and Mad scholars, community members and allies debate regulations and practices related to disability selective abortion (Hubbard, 2006), facilitated sex (Sanders, 2007), medically assisted dying (Cochinov and Frazee, 2016) and disabled parenting (Ignangi and Fudge Schormans, 2016). However, intimate constraints in high-support housing in Ontario, a service designed as a means of ending custodial housing and promoting empowerment, have yet to be interrogated in this way.

Social reproduction and eugenics. Mad \& Disability studies lenses can bring to the discussion of social reproduction the long history of oppression exercised over the lives of labelled people, which includes the eugenics movement, an ableist/saneist, racist, sexist, homophobic and colonial movement that targeted bodies deemed 'less desirable'. Attention to this history of eugenics when employing a feminist political economy lens allows scholars and activists to observe how the work of social reproduction can be a key site through which eugenics in enacted. In addition to justifying racial hierarchies and the murder of racialized people, Queer people and disabled people (to name a few), the eugenics movement has given rise to numerous mechanisms for controlling who reproduces and how people reproduce (Hubbard, 2006). Examples of these mechanisms include the sterilization of people deemed 'biologically inferior', including disabled people (Hubbard, 2006), Black people (Roberts, 1997) and Indigenous people (Stote, 2015), and, with specific reference to the context of mental health care, the mental hygiene movement, which targeted, among other things, parenting practices as a means of weeding out 'maladjustments' (Simmons, 1990; Dickinson, 1993).

More recently, the conversation in Mad \& Disability studies has shifted to neo-eugenics, a term that typically refers to the use of genetic and reproductive technology to enhance the "human stock.' However, as scholars such as Ignangi and Fudge Schormans (2016) demonstrate, neo-eugenics is not limited to medical technologies, but also involves limitations imposed on the social reproduction of people marginalized by the constructs of race, gender, and class. Key examples include state supervision of parenting practices and child apprehension due to markers of disability, poverty and cultural 'difference', and a lack of supports for parenting among the unemployed.

When considering neo-eugenics in relation to social reproduction it is indeed useful to employ an intersectional lens. 
Intersectionality, as feminist political economists have demonstrated, allows for attention to the specific ways the arrangements of social reproduction are gendered, raced, and classed (Vosko, 2002). However, because feminist political economy scholars have been less attentive to issues of disability, analyses of how arrangements of social reproduction can deny or limit the participation of labelled people in this socially necessary work have not been sustained. Often, as I demonstrate in this paper, labelled people are identified as solely 'care receivers' (Tronto, 1993) and unproductive both in relation to surplus production and social reproduction. This annexation of some disabled people from participating in social reproduction is indeed a form of neoeugenics which, as discussed above, are experienced differently in relation to race, gender, class, and other social locations. The paper demonstrates the utility of blending Mad \& Disability studies and feminist political economy for understanding the ongoing oppression and marginalization of disabled people. It does not robustly employ an intersectional lens. This, however, is the next step in 'cripping' or maddening feminist political economy for the purpose of more fully understanding intimate constraints.

Eugenics and neoliberalism. Current limitations and control exercised over the lives of people with mental illness labels is a manifestation of the neoliberal ethos of individual responsibility and a complementary organization of social reproduction. Under neoliberalism, the state and employers are providing fewer resources for social reproduction, making people more dependent on the labour market (Bezanson and Luxton, 2006a, b). Within this context, individual independence as the hallmark of 'good citizenship' is being written into social policy.

In Ontario specifically, the adoption of neoliberal policy making in the last three decades, arguably entrenched by Premier Mike Harris' 'Common Sense Revolution', has fundamentally changed Ontario's social welfare system, one component of which is the public mental health care system (Gray, 1999; Keil, 2002; Wilton, 2004; Chouinard and Crooks, 2005; Wiktorowicz, 2005). Workfare, welfare stratification between the deserving and undeserving poor, low income support rates, long wait-lists for social housing, criminalization of poverty and 'mental illness', and a downloading of much responsibility for social services to municipalities and the third sector, are just a few of the ways in which market logic and individualism shapes how Ontarians do the work of social reproduction. Social reproduction has become an individual responsibility, and those who cannot complete this work without state supports are viewed as 'irresponsible', especially when they have children that also require state supports.

Precisely because the work of social reproduction is an essential site of control and limitation of reproduction and parenting, the insights of feminist political economy scholars into the implications of neoliberal policy (re)making for the terrain of social reproduction is especially useful in considering control over intimate life within high-support homes in Ontario. The feminist political economy lens allows us to correctly identify high-support housing (and the mental health care system more broadly) for what it is, a network of supports for social reproduction. Indeed, mental health care services, be they clinical housing, disabilitybased income support, or treatment services, are all directed towards the reproduction of labelled people. As a set of services for social reproduction, mental health care is shaped by the prevailing economic ideology and dominant understandings of mental illness communicated through social policy (Morrow, 2004) as well as through processes of service provisioning. Together, economic ideology and the dominant understandings of mental illness define who is targeted by or has access to the system, what kind of services are provided, and, importantly, what goals are informing this system of 'care.' Mental health care service provisioning is a system of social reproduction, but it is also a mechanism through which power is enacted over the lives of those labeled mentally ill.

This power is sometimes difficult to observe as it is not enacted through a centralized institutional state arrangement, but through non-profit organizations, charities and community groups. These seemingly extra-state organizations are, in fact, key sites where state power is deployed. The state, while relatively autonomous, employs different kinds of power through numerous institutions and practices (e.g., police, social workers, and the military) (Brown, 1992). This idea of disparate forms of state power is especially important when examining intimate constraints in high-support housing. The constraints arise from the policies operating at multiple levels of government and within and across different government departments, as well as through housing regulations, the practices of non-profit organizations and services providers. It is these service providers and non-profit organizations who, through decades of patient neglect and downloading on the part of the federal, provincial and municipal governments, have become the primary caregivers for those living in highsupport housing.

Each entity targeting the needs of residents shares a common fealty to market logic, the medical model of mental illness, and the promotion of attendant subjectivities of individualism and personal responsibility coded in the language of the psydisciplines and therapeutic intervention. It does bear noting, however, that in the case of non-profit organizations and frontline service providers, this fealty is often a condition of funding, and may or may not reflect their preferred approach. The 'convenient marriage' (Moncrieff, 2008) of medical models of mental illness and neoliberalism are what shape public mental health care, which is a system of social reproduction, and it is in these two factors that the limitations and control over residents' biological reproduction and parenting choices can be located.

\section{The historical context}

The mechanisms of constraint operating under Western capitalism in the intimate lives of people with mental illness labels, and all people with disability labels, have a long history. They can be located in the classed, gendered, raced and cisheteronormative pathologization of people displaying non-normative bodies and minds, the unemployed poor, those who violated the prevailing social order (e.g., 'single mothers', Lesbians), and state intervention into family practices that characterized the Enlightenment and industrialization (Cohen, 2016). These developments were followed closely by the birth of the eugenics movement in the early 1900s, a movement which deployed Darwinism under the umbrella of improving the human race 'scientifically' (Davis, 2006; Hubbard, 2006; Cohen, 2016; Martel, 2016). The eugenics movement consisted of an entanglement of 'scientific' racism, colonialism, antisemitism, and heteronormativity, as well as ableism and saneism, all of which are underwritten by a concern about the financial burden created by the poor and people with disabilities (Cohen, 2016). Under the banner of 'improving the human race,' sterilization, murder, institutionalization, and scrutiny of, and supervision over, family life emerged as state projects.

While the government of Ontario, unlike that in Alberta, did not implement an official practice of sterilizing people labelled as mentally ill or disabled in some other way, the eugenics movement was embraced by influential medical practitioners in the early 20th century such as Dr. Helen McMurchy, Dr. C.K. Clarke, and Dr. C.M. Hinks, and measures for implementing a eugenics 
policy were publically discussed and debated (Rossiter and Clarkson, 2013). Ontario witnessed (and continues to witness) the effects of this eugenic ideology in social policy and the practices of service providers. The popularity of eugenics in Ontario, it is argued, supported child classification and apprehension, the removal of people labelled 'mentally deficient' or 'feeble-minded' from the population through institutionalization and informed legislation, specifically the Act Respecting Houses of Refuge for Females, 1913, which restricted women labelled as 'feeble-minded' from leaving custodial care (Rossiter and Clarkson, 2013). Eugenics also informed the mental hygiene movement, popular in Ontario and throughout North America during the first half of the 20th century (Dickinson, 1993). Embedded in a preoccupation about the state of the population, the desire to address a number of social problems such as 'poverty, crime, juvenile delinquency...insanity... and feeblemindedness' (Dickenson, 1993, p. 339) and a preoccupation with the reproduction of a healthy and productive workforce, the mental hygiene movement sought to prevent mental illness through community-based responses to 'incipient maladjustments' (Simmons, 1990, p. 50). Although the mental hygiene movement fell out of favour in the mid-20th century, the institutions and professional associations dedicated to intervening in the 'intimate lives' of people who occupy categories of embodied difference remained in place, as did the medical models that identify disability as solely an individual problem.

Those communities who experience such pathologization, including the Mad, Deaf and disability community, have done a great deal of work to confront the use of scientific discourse in the legitimization of pathologization, bodily hierarchies and attendant oppressions, and secure institutional protections against discrimination nationally (e.g., the Canadian Charter of Rights and Freedoms) and internationally (e.g., the UN Convention on the Rights of Persons with Disabilities). However, the gendered, raced, classed and cisheteronormative hierarchy of human bodies, and a preoccupation about which bodies reproduce, what kinds of bodies are reproduced, and what social norms are cultivated through family structures and practices remains in place, mobilized in new ways with the (re)penetration of market rule in all aspects of life under neoliberalism (see, for e.g., Hubbard, 2006; Smith, 2010; Murray, 2015; Ignangi and Fudge Schormans, 2016). It is within the current conjuncture that the intimate constraints in high-support housing in Ontario can be located.

In choosing biological reproduction and parenting, I do not mean to suggest these are the only two forms of intimate constraint experienced by residents. Readers of this article will get a glimpse into limitations and control over the sexual and romantic lives of residents, as it is not always possible to discuss one facet of intimate life in isolation from others. I chose biological reproduction and parenting as these were the themes that emerged in my conversations with both service providers and residents across the sites.

\section{High-support housing}

As stated, high-support mental health housing is one type of housing in Ontario's supportive housing network. In the province of Ontario, there are more than $23,000^{1}$ mental health \& addiction' supportive housing units, characterized by a focus on recovery and independence (Suttor, 2016). The development of supportive housing for people labelled as disabled in Ontario emerged in response to concerns about the custodial nature of existing housing programs, such as boarding homes, which developed following deinstitutionalization, and the creation of new institutional forms of care (Suttor, 2016). The situation in psychiatric boarding and rooming homes in Ontario, and in particular in Toronto, was well mapped by residents and scholars alike, as well as, eventually, by government (Marshall, 1982; Mayor's Action Task Force on Discharged Psychiatric Patients, 1983, 1984; LaCroix, 1986; Mallory, 1986; Building Community Support, 1988; Capponi, 1992; Putting People First, 1993). The academic and activist literature, as well as government documents, drew attention to the unsafe infrastructure, lack of cleanliness, unacceptable food, deaths among residents and the institutional-like conditions within these spaces. Government attempted to better regulate this type of housing, but concern over the custodial nature of the homes continued. Supportive housing is intended to continue the project of replacing custodial housing programs that operate from a one-size-fits-all approach to service provisioning, within which the focus is on deficit rather than on individual needs, capacities and recovery models and which have been critiqued as recreating institutional-like conditions (Ministry of Municipal Affairs and Housing, 2014; Suttor, 2016). According to the 2017 Ontario Supportive Housing Policy Framework, 'supportive housing should be governed by...recovery based principles' (p. 8). Recovery, according to the province, is about 'personal hopes, dreams and goals'. Recovery is 'a personal process that people with mental health needs experience in gaining control, meaning and purpose in their lives', including everything from living without 'symptoms of mental illness' or 'learning to live with on-going symptoms' (p. 8.).

Supportive housing is typically provided by non-profit organizations, with funding coming from different federal and provincial government departments as well as municipal governments, and is often allocated through competitive grant applications. As stated, the Ontario government is currently focussed on strengthening the supportive housing network in the province, having promised over $\$ 178$ million over the next 3 years as a means of 'chronic homelessness' and up to 1500 new units in supportive housing (Ministries of Housing and Municipal Affairs; Government of Ontario, Newsroom, 2017). It is within this recovery focussed housing network in Ontario, that highsupport programs are located.

In the homes the staff members provide support for the activities of daily living, such as laundry, cooking, light maintenance, cleaning, medication and money management, as well as supports around doctor's appointments, income support, travel, transportation and recreational and occupational activities (Toronto Mental Health and Addictions Supportive Housing Network). Residents also engage in the work involved in running the housing sites by doing cleaning, light maintenance and running errands. Although residents do some of the work involved in the daily reproduction of the high-support community, they experience significant constraints upon their capacity to engage in biological reproduction and parenting. In the next section, I consider these constraints,

\section{Intimate constraints in Ontario's high-support housing system}

The mental health care system. The structure of mental health care and the dominant understandings of mental illness communicated through this system are central to understanding the intimate constraints with which this inquiry is concerned. A brief look at Ontario's most recent mental health care strategy, Open Minds, Healthy Minds, 2011 (OMHM) (notably the first strategy since the early 2000s), provides a useful overview of the ethos of the mental health care system. The goals of this strategy, which informs mental health care delivery across the province, are to help people with 'mental illnesses' 'access the social determinants of mental health' (p. 12), foster 'resiliency' to deal with the ups and downs of everyday life (pp. 7, 9), promote appropriate service 
use as a means of reducing 'the personal, social and financial burdens of mental health and addictions' (p. 4) and 'lower the per person cost of mental health and addiction services' (p. 8). Underpinning this strategy is the message that there is a symbiotic relationship or pseudo-virtuous circle among economic growth, service retrenchment, and service user well-being.

The projection of neoliberal market logic onto the figure of the 'mental patient' has produced an ideal patient type, one who mitigates the financial burden their impairment poses to society by assuming the trappings of individual responsibility. 'Mental illness' is perceived as a burden and as an individual biological problem. Wiped away are the long history of state control, lowrates of income support, long wait lists for social housing, and high rates of precarious employment and unemployment that impact people labelled mentally ill. The role of systemic oppression is not provided as the context for the 'ups and downs' and the need for resilience. Instead, labelled people are expected to 'access the social determinants of health' and learn individual responsibility to mitigate their burden to society.

OMHM not only informs how government departments act in delivering mental health care, but it also sets the parameters for the provinces 14 Local Health Integration Networks (LHINs), and informs how third-sector service providers, dependent on the province for funding, write their grant applications and engage with their 'clients' (LHINCollaborative, 2010; Central LHIN, 2012). As I will show in the next section, the ardent focus on individual independence, coded as recovery, the mechanisms of service provisioning designed to elicit such independence and the on-going problem of low welfare rates and insufficient housing place significant constraints on the intimate lives of residents alongside more overt practices of control.

Resident experiences with biological reproduction and parenting. Laxer and Armstrong (n.d.), two feminist political economists, argue that we must be as attentive to the silences in our data as we are to the noises. Two of the major 'silences' I observed during my field work were: (1) the complete absence of children within housing sites for adult men and women, and (2) that none of the residents were pregnant or mentioned wanting children. I, therefore, began asking residents about their parenting status. Seven of the twenty-three residents I interviewed identified as parents (some did not discuss parenting status). Many of the residents with children were unwilling to provide details of their parenting relationships, reporting that they had children but were not in contact or were vague about their parenting status. For example, when asked if they have children, residents who did not disclose in depth details, but who agreed to be quoted, stated the following:

\section{One, I don't know where $[\mathrm{s} / \mathrm{he}]$ is.}

I do and I don't....I rarely answer that...

One [gender of child] who goes to university.

One person, who did not wish to be quoted, disclosed that they were told explicitly not to have children (but did not say by whom). Only two reported regular contact with some of their children.

Two women did speak at length about the frustrations they encountered maintaining relationships with their children. The first woman who spoke at length, who I will refer to as Jane (pseudonym), lived in a psychiatric hospital for many years, and sees her eldest child regularly, but spoke of her frustrations when trying to contact her youngest.
I keep asking [worker] to contact me so I can go and visit [the now young adult child and] see how [they are doing] in school.... [The worker] tells me [the child] is [doing well and] doing well in school. And that is all I get. I miss my [children].

Jane credits her children for her ability to avoid self-harm and ended our interview by stating, 'I just want to be happy, and I hope... my kids are happy without me'.

A second woman, who I will refer to as Dawn (pseudonym), also lived in a psychiatric hospital for many years. Following her hospitalization, she lived with her children and spouse. When I asked her if they visited her, she indicated that they are not allowed to do so at the moment mentioning both the police and an inability to reach her spouse on the phone. Both of these women expressed distress at the current situation and their continued efforts to support their children. As I demonstrate in the next section, there is very little in the way of supports for these women to reconnect with their children or for any resident who wants to engage in biological reproduction and/or parenting.

Along with the lack of children and partners in the homes, the short answers many residents gave about their parenting experiences indeed represent a silence. Given the long history of eugenic and neo-eugenic practices in Ontario and the pain that separation from children can bring, I did not ask follow-up questions when residents disclosed parenting statuses. Rather, I left space for residents to discuss their biological reproduction and parenting experiences as they saw fit. This general 'silence' around parenting should not be taken as evidence that residents are uninterested in biological reproduction and/or parenting. Rather, as a researcher, I can speculate this silence speaks to the fact that residents were not interested in disclosing their stories about their biological reproduction and parenting activities and constraints to me at that time. I can also speculate, given the other information that was shared with me by residents (discussed below), that this reluctance is rooted in the fact that all residents experienced long periods of psychiatric hospitalization, which removed them from their communities, families, friends and opportunities for employment and placed them under state and medical scrutiny. This form of social and economic exclusion not only can result in loss of children, romantic and/or sexual partners, but can also foreclose opportunities to acquire the means necessary for building or maintaining a family life. Therefore, providing details on biological reproduction and/or parenting experiences (or lack thereof), would likely require some residents to reveal, in detail, their interactions with the psychiatric system, poverty, incarceration, family conflict, and/or interactions with CAS.

Considering the regular appropriation of the stories of people with mental illness labels by mental health organizations (Costa et al., 2012), the sometimes painful experiences of residents, and the high rates of daily surveillance by staff, medical practitioners, and case workers, it is not at all surprising that people were reluctant to disclose. Beyond speculation about the conditions that made residents reluctant to speak in depth about biological reproduction and parenting practices, the silences of residents can also be recognized as an agentic act, a decision to not turn their experiences into research data at that time, and a means of preserving their own safety in the face of a social service system that can bring with it a great deal of punishment if someone is seen as breaking the rules. Although many residents chose to share only a small portion of their biological reproduction and parenting experiences, the information they did share, and their general observations about life in the homes, along with staff observations, provides important insights into the constraints on intimate life in high-support housing. There is, however, a great 
deal more work that needs to be done on this topic and in some ways, this paper raises more questions than it answers as a means of opening up space for this important conversation.

The constraints. Scrutiny over daily life is a regular feature of high-support housing as is considerable freedom; once again reflecting the contested nature of these housing sites. Residents have considerable freedom in relation to those hours not devoted to 'recovery' activities. During this time residents engage in their own chosen activities, which included music, art, cooking, crafts, exercise, part-time employment and socializing.

At the same time, daily life involves medical appointments, social worker appointments, medication regimes, recreational and occupational therapy, organized outings and, in some sites, cleaning and running errands for staff. These tasks are linked to the expressed goals of the staff which are to keep residents out of the hospital, 'stable' and working towards greater independence. Contained in the design and processes of service delivery are certain yardsticks for wellness that reinforce individual independence in daily maintenance.

Through conversations with the staff, I learned that independence in daily maintenance is indeed central to how wellness is perceived. The 'ability' to manage one's own medications (a very rare occurrence), a willingness to take medication, to be employed, to manage money, to keep units neat, to run errands for staff and to volunteer outside the home are all markers of wellness and recovery. For example, when discussing resident work one service provider stated that '[one resident] was good enough to work for [a particular company]'. In this context good enough means well enough. Motivation to make coffee, look for work or join in activities was also referenced by staff as an indicator of wellness. Many residents I spoke to also identified a lack of employment as an indicator of being 'unwell'.

Although greater independence, when desired by residents, is not a problematic objective, this model of wellness and recovery, that which is expressed in government strategy (OMHM) is relatively limited to those activities of individual completion of daily maintenance. When independent completion of the activities of daily living is the clinicalized hallmark of well-being, there is little room to offer supports for or imagine residents engaged in social reproduction within a family setting. The very rubric for measuring progress is based on a life contained within the individual body. Moreover, when independence becomes a marker of wellness, interdependence becomes devalued and, in the case of people living with mental illness labels, pathologized. When a person with a mental illness label needs state supports, that need becomes pathologized. Living within pathologized relationships of interdependence, whether desired or forced upon residents, brings with it certain conditions.

One of these conditions is that children cannot live in highsupport housing. Neither can partners. High-support housing is typically based on a model of a single resident or occasionally shared occupancy units. As one resident stated, '[to live here you] have to be single and you have to [have a psychiatric diagnosis]'.

When I probed the issue of the absence of partners and children, it was confirmed that children and partners, while permitted to visit, were not permitted to live in the homes, even though, as one service provider stated, residents 'have every right as everyone else under the RTA [to make such use of their space as they see fit $]^{\prime 2}$. One resident informed me that in past years romantic and sexual partners could stay over in a particular site, but that the current director of the program did not like this. At another site guests can stay 'up to a week'. Another resident disclosed that they would like to move so that they could 'have a girlfriend'. These limitations on who can live in the units, provided the units are large enough, are likely a violation of tenant's rights under the RTA. According to the Social Justice Tribunals in Ontario, which incorporates the Landlord and Tenant Board) (n.d.) 'a person may be an occupant of a rental unit provided that person has the consent of the tenant to live in the rental unit and the person's occupancy of the rental unit does not result in overcrowding within the meaning of section 67 of the $\mathrm{RTA}^{3}$ (Para 29), which deals with overcrowding (discussed below). The official explanations for no children and partners across the sites was that the units were not equipped for other people, that it would be very difficult to sort out the housing subsidies and that residents had lost physical custody of their children prior to coming to high-support housing.

'Equipped for other people' could be a reference to bylaws that dictate occupancy, which differ across the province but which are incorporated by reference into section 67 of the RTA. In the larger cities such as Toronto, London and Ottawa, occupancy (other than that in government provided housing ${ }^{4}$ ), is based on the size of the units and rooms. For example, in Toronto where there are multiple people occupying 'habitable rooms' each person must have nine square meters of space except in rooms designed for sleeping which, with multiple occupants, require four square meters per person (Toronto Municipal Code. Chapter 629, Section 25). In Ottawa, children under twelve count as half a person (Ottawa, Property Standards Bylaw, 2013426, Section 3(a)). Either people in high-support housing are living in such small quarters that they cannot have their partners or children reside with them or children and partners are being unfairly excluded. Having spent time in the units, but not having measured them, I suspect it is a combination of both bylaw restrictions and housing rules that may violate residents' rights as tenants, and may, as a result, be restricting freedom over biological reproduction and parenting.

There is little opportunity to ignore the rules and construct the family life a resident desires. Guests, typically, have to sign in and out, and there is staff on site all day, if not $24 \mathrm{~h}$ a day, administering medication, money, and cigarettes, and coordinating appointments with doctors and social workers. 'Breaking the rules' is an option for other people whose housing is not provided through government programs and/or who live with less scrutiny. The practice of having multiple people live in single rooms or one-bedroom apartments is certainly not rare in Ontario where in $2011,7 \%$ of households were considered living in 'overcrowded' conditions (Statistics Canada, 2011). This number was higher in Toronto where housing costs often far outstrip what is affordable for people making minimum wage or welfare (CMHC, 2015), and where waiting lists for housing subsidies are years long $(\mathrm{CAMH}$, 2012; ONPHA, 2016). The option to live with a child or partner in a small unit is not available for residents in high-support housing because of funding arrangements, and day-to-day schedules which are not created for parents or children and, as mentioned, the high rates of surveillance in these homes.

What is more, I suspect that the long-history of institutionalizing and then warehousing people with mental illness labels makes service providers wary of overcrowding or creating an institutional feel-which, as outlined above, was one of the reasons supportive housing was created (Suttor, 2016). Limitations on how residents use the space arising from fear of recreating institutional conditions is, however, nothing more than a deployment of past oppression to legitimize its current form and involves identifying limitations on resident bodies as the solution to the underfunded housing and social services system.

Although nearly a third of the residents I spoke with identified as having children, staff said very little about parenting. In fact, in some sites there were contradictory reports from staff about the number of residents with children. The lack of staff engagement 
with parenting tasks was surprising, as cultivating family support for residents is one of the tasks discussed by service providers as well as in current mental health strategy (Open Minds, Healthy Minds). Staff across sites spoke at length about the amount of work families do to support residents and the role of staff in fostering and sometimes intervening into these relationships. Staff did not discuss working with residents on parenting or the importance of children in the lives of some of the residents. One staff member, when asked specifically about cohabitating with a spouse, simply stated that the '[residents] come to us with no attachments'. However, two residents disclosed on-going relationships with people outside the home. Despite these existing relationships, parenting, romance and sex were simply not central to the conversations around cultivating family support and relationships.

There is also, somewhat contradictorily in light of casting residents as without attachments, a staff focus on outside 'attachments', but the emphasis is on relationships with biological family members, particularly parents and siblings, those relationships that support residents' own reproduction rather than supporting residents to engage in biological reproduction or parenting. This focus on downloading some responsibility for residents to their own families mirrors the privatization of social reproduction outside of the high-support system documented by feminist scholars (McKeen and Porter, 2003; Bezanson and Luxton, 2006a, b).

There is a great deal of uncertainty among residents as to what would happen if someone became pregnant or wanted to live with a partner. Some residents were very clear that it was not permitted, while many-including some with children-stated they did not 'think' that children and partners could live with them. One resident informed me that 'they [the staff] don't really talk about it so no one is [cohabitating]'. The lack of clear information about resident rights and options, while not an overt form of constraint, represents a lack of consideration on the part of government and third-sector programs and service providers for the wants and needs of residents beyond the reality of day-today survival and medical treatment. This limited view of what is possible for residents and the attendant lack of information creates additional barriers to considering, creating or maintaining a family life when living in high-support housing. In some ways, the lack of clear information can be understood as a form of coercion. Without access to information as to what will happen to their housing if they engage in biological reproduction and/or parenting, residents are unable to weigh the risks associated with intimate activities and to make an informed choice. This lack of information, coupled with the affordable housing crisis in Toronto, could create conditions under which residents felt that they had no choice in the matter if they wanted to remain housed, forcing them to shrink their 'personal hopes, dreams and goals' (Ontario Supportive Housing Policy Framework, 2017, p. 8) to fit the housing system. This form of coercion is sometimes difficult to see as it does not extend from one source, but rather from economic insecurity, a lack of housing options and significant state scrutiny over the biological reproduction and parenting activities of people labelled mentally ill.

Indeed, the idea that residents could engage in active parenting was, quite simply, absent. Moreover, the challenges residents experienced in creating or maintaining parent-child relationships were largely dismissed as a result of the 'mental illness' and/or previous interactions with Child Advocacy Services (CAS). There was little consideration as to how high-support housing fits into the wider systemic denial of reproductive and parenting freedoms among people labelled mentally ill. In short, high-support housing is structured in a way that denies residents the freedom to parent or, given the control over guests, engage in the sex often required for reproduction within their own home. The structure of housing denies residents the opportunity to create or maintain relationships with their children, regain physical custody or plan to have children and stay in their unit.

Readers may be wondering why residents do not simply move into different housing. This could be a solution, but, as stated, there is an affordable housing crisis in Ontario. Waiting-lists for supportive housing typically stretches into years (CAMH, 2012) and there are more than 170,000 households on the waiting list for rent-geared-to-income alone (ONPHA, 2016). As discussed below, staff is sometimes reticent to move 'clients' who develop parenting or romantic relationships for fear these relationships will fall apart thus not 'allowing' residents to take a very common risk. Moreover, for those residents who may want to leave highsupport housing, but who still desire housing with supports, there are very few options for family housing within the supportive housing system-something I discovered when reading the application for supportive housing (The Access Point, n.d.). The lack of supports put pressure on those who want to have children and parent to obtain housing outside of the subsidized and/or supportive housing system. Given the unaffordability of safe and secure housing in Ontario discussed above and the widespread poverty and precarious employment impacting people labelled mentally ill (Statistics Canada, n.d.) and lowrates of income support, moving out is often simply not an option. Furthermore, if a resident was able to move out, but unable to access the necessary supports to complete biological reproduction or parenting in a way deemed acceptable by the state, that person would face the prospect of losing their children. To further complicate matters, if the person was also accessing income support, with the loss of custody the income support could decrease, and they would likely, as a result, have to move (Ontario Disability Support Program, n.d. Directive 2.2). In essence, to be 'allowed' to parent, a resident must first demonstrate recovery (i.e., independence) and an ability to complete the work of social reproduction without a high level of supports. Once again, a lack of housing for families, a lack of economic security and state surveillance come together to discourage residents from reproducing or parenting. Furthermore, as this next section demonstrates, this lack of services coupled with intense surveillance creates conditions under which pregnancy and parenting is considered a 'problem' to be avoided.

The lack of space for children within the homes and the relative lack of other options within Ontario's housing system contributes to anxiety over the biological reproductive functions of residents, with specific implications for women. Pregnancy was largely framed as a 'problem', with staff stating the following when asked what would happen to a pregnant resident. It is important to note that the issue of birth control was not discussed in every site.

[Residents] are too old and we are tight on this. We [wouldn't let that happen]... those who need [birth control].... were put on it a long time ago.

Anyone who is vulnerable... their Doctor is prescribing [birth control] and they are getting it with their meds...

[Within the larger supportive housing system] we support families where maybe the head of the household has a mental illness. [Yet], $99 \%$ of the time the baby is taken away. [New housing will not be secured] until we can be assured that they are going to keep [the baby]. Because CAS comes in and takes [the child] away.

The need to control residents' reproductive life, either by controlling their movement and activities or through the 
prescription of birth control by physicians, is framed by staff in terms of protecting residents from the hardship they might encounter in light of the active pathologization of poor, disabled and Mad parents and the absence of supports for the work of social reproduction. Regarding the prescriptions for birth control, which was presented as a protective measure by staff (see above), it was difficult to ascertain whether or not it was mandatory. In some of the sites where birth control was prescribed, residents are obligated to take their medication and medication is administered by staff daily to the majority of residents. Staff in sites where medication is mandatory stated the following:

They have to take the medication, it is mandatory.

They sign an agreement...you agree to be live here, you agree [to be] compliant with whatever the doctor orders.

Although it was unclear as to whether or not birth control, when prescribed by a physician, was part of the mandatory medication regime, the image of staff administering or coordinating birth control alongside often mandatory psychiatric medication raises questions about whether or not residents feel they are able to decline birth control. This is especially true when birth control and other monitoring is presented as a means of protecting residents from hardships. Certainly, requiring people to sign an agreement to take medication while a resident in highsupport housing can be understood as a form of coercion similar to life in institutions. However, the hardships that can be experienced should biological reproduction and parenting take place are also coercive, grounded not in a specific rule or piece of legislation but in the simultaneous, and contradictory, erasure of residents' capacities for these intimate activities and the pathologization of both poverty and disabled parenting by service providers and within state policy.

The activities of CAS are a key example of the kind of hardships the staff is seeking to mitigate. The statistic of $99 \%$ above is likely hyperbole used to demonstrate the high frequency at which clients throughout supportive housing are losing custody of and access to their children. While some of the residents did not have physical custody of their children and at least one reported CAS involvement, most had-according to staff- lost custody prior to living in high-support housing. Living in highsupport housing, however, is clearly a barrier to regaining physical custody as children cannot live in these homes. Unsurprisingly, none of the residents spoke about trying to regain custody of their children when parenting was raised. Again, it would be inaccurate, considering Jane and Dawn's stories, to argue that this silence around desire for custody or the live with their children means that children are not a concern to residents. Rather, the information and infrastructure is not in place to pursue this option. This is a constraint which is underpinned and legitimized by staff concerns about child apprehension.

Statistics about the rate at which children are removed from the custody of parents labelled mentally ill are not available for Ontario but overall admissions of children into care have declined and discharges have increased since 2014. However, parents with mental illness labels are being unfairly targeted. According to the Ontario Family Risk Assessment Descriptors Neglect Index assessment tool, if the primary parent or caregiver has a current or past 'mental health problem', the 'risk score' increases. The risk score also increases when indicators of poverty are present, such as infestations, inadequate plumbing or heating, and inadequate winter clothing. Given the high rates of poverty among people with psychiatric diagnoses, especially those accessing support services, and the fact that the mere presence of a psychiatric diagnosis increases the 'risk score', the frequency of removal cited by the worker in the above comment is not surprising. It is, however, deeply troubling that parents with psychiatric labels appear to be unfairly targeted and scrutinized by CAS, and the approach taken by CAS to people with mental illness labels speaks loudly about who is, and who is not, valued as a reproductive member of society.

Staff members were acutely aware of the realities of child apprehension and other consequences emerging from a mental health care system that is underfunded, and in the context of which child apprehension is reported to be a regular occurrence. The staff members I spoke to all worked beyond the parameters of their jobs and their paid hours in pursuit of supporting the residents and filling in gaps in service provisioning. Staff reported performing tasks such as offering counselling to family residents who were not 'clients' and travelling with residents who needed a companion. In describing over work staff made statements such as the following:

There are not enough hours in the day and week to get it all done. You do go beyond...you don't go 9:00 to 5:00 and say, "well, it's 5:05 pm I am not going to pick up this call".

[Doing everything that is needed] is the secret. [That is] why we look askance at some of these agencies who come in with a list they need to check off and [then leave].

All of the staff members were critical of the mental health care system, and were focussed on the need for more resources for people labelled mentally ill, especially in relation to rates of income support and access to safe and affordable housing. A number of the staff I spoke to were wary of the regulations around children living in the homes, and suggested ways children could remain with their parents. Examples include having the housing organization absorb any related costs and a pilot project for mothers. However, one solution to these wider systemic issues was further limiting the reproductive freedoms of the residents, either through the prescription and administration of birth control, keeping a close eye, or simply presuming that residents would not be able to parent.

It would be easiest to dismiss these intimate constraints on residents as simply the result of poorly run housing or the unfortunate experiences of a few residents. While I would not universalize the intimate constraints experienced by the residents I interviewed, we can draw some conclusions about the context in which these constraints are occurring, namely a mental health care system where the biomedical model of mental illness remains dominant, individual responsibility is equated with wellness and cost reduction is a central goal. Within this mental health care system, people accessing high rates of public support, such as residents of high-support housing, are routinely identified in social policy and practice as unwell and costly. For example. These costly bodies are constructed as problematic, targeted by emerging recovery strategies within which independence from state services is the measure of well-being and one of the only avenues to autonomy over social reproduction. This focus on cost reduction manifests not only in strategies of 'efficient program delivery' but also in subjectivities of mental illness that align with a lean mental health care system, specifically the promotion of the ideal 'mental patient' as one who mitigates their own burden on society. This is the public mental health care system within which high-support housing is situated in Ontario.

Responsibility, defined in terms of biological reproduction and parenting, means caring for the self and family using as few state services as possible. Irresponsible people, parents, and citizens are those who use 'too many' social services in completing the work of biological reproduction and parenting, and are often identified as having 'too many' children they cannot afford, especially in the 
case of racialized people and/or low-income earners (Davis, 2009). These limitations are underpinned by the widespread notion that people with mental illness labels, certainly while accessing such a high level of support, are unfit to be parents and unable to manage parenting relationships. These assumptions cannot be separated from the widespread idea that people, and especially women, who are experiencing economic hardship, criminalization, and/or problematic substance use should not have children (Smith, 2010), most recently visible in the offer of reduced prison terms in exchange for temporary or long-term sterilization in Tennessee (Dwyer, 2017). The denial of freedoms to reproduce biologically and through parenting stems from three assumptions. First, that the presence of a psychiatric diagnosis results in less desirable parenting and, therefore, less desirable children. Second, that people accessing state services should devote their time to becoming more independent, which, in the case of disabilities, is coded as wellness. Third, that the work of social reproduction, the reproduction of the population intergenerationally and daily, is an individual rather than social activity that one must not participate in until doing so can be supported entirely through participation in production for surplus (i.e., employment).

\section{Conclusion}

The geography of social reproduction within high-support housing, and the broader network of social supports within which high-support housing is located, is one aspect of the limitations and control exercised over the social reproduction of residents. It is difficult to see such spatial arrangements as anything other than a continued assumption that people labelled mentally-ill cannot parent. The parenting responsibilities and desires of residents may not have been taken into account when designing the homes because many had lost contact with their families or custody of their children during institutionalization or another event. However, the perpetuation of these barriers to residents obtaining or maintaining a family life is a continuation of the removal of the 'mentally deficient' from the population and parenting roles, that is, a removal from the work of social reproduction.

Given the devastating effects for both parents and children of forced separation by the government and the eugenic nature of controlling who reproduces, more research needs to be done on when, and why, people with mental illness labels with children lose custody of them. Such research would be an especially timely contribution to scholarship exploring how public policies, especially those targeting children and women, are being designed to produce political subjectivities compatible with the current processes of capitalist accumulation (Smith, 2010; Murray, 2015).

It is almost certainly cheaper to limit the reproductive and romantic lives of residents than it is to reorganize existing, or provide new, services that would allow residents greater autonomy over how they construct their lives. Moreover, it is certainly seen as less of a 'burden' on social services to limit reproduction than it would be to provide services for a person accessing the mental health care system as well as their children. Rather than offering (potentially more costly) supports for parenting, children are simply removed from the custody of people with mental illness labels, and both subtle and overt understandings that such people should not parent are deployed to legitimize these removals.

These limitations on the lives of residents reflect the desire to reduce the cost of mental health care and foster independence as the central goal of the mental health care system. First, they contain the use of housing supports, as well as income supports, provided to service users to meet only their own daily needs and not the needs of a child or partner and child. Second, building on Smith's (2010) argument that the sexual regulation of people accessing welfare produces a flexible childless worker, these programs ensure that the energies of service users are directed not at reproducing life intergenerationally, but rather at the work of acquiring independence in daily maintenance, ideally through employment. Third, and less overt, the limitation quells the social anxiety, visible in the rise of prenatal testing and human genome mapping, that people with mental illness labels will pass these traits on to a child, who will then, in turn, be dependent upon social services. These eugenic, or perhaps, in keeping with Smith's (2010) language and the emerging terminology, neo-eugenic policies and practices directly protect public funds from the mentally ill, and are, regrettably, a predictable feature of a neoliberal mental health care system. Neoliberalism may indeed be 'new', but intimate constraints are regrettably an old story.

Going forward, especially as new supportive housing is being created, it would improve the mental health care system if funding was provided to increase the number of units that are large enough to allow families as well as lift the ban on children and partners within high-support housing where the space regulations are met. Such changes would interrupt the problematization of resident reproductive function that arises from concern over the housing crisis and/or child apprehensionespecially in the case of those who can bear children. It would also be important, in the interest of ensuring resident freedom over biological reproduction and parenting, to ask residents how the processes of service provisioning can be altered to offer greater support to residents who want to have children, who want to establish physical custody and/or who want to establish more regular contact with their children. Resident-led changes are of utmost importance as it the residents who know best what they need. Finally, there is a danger that allowing children and partners to live in high-support housing will increase state scrutiny in the lives of residents, thereby re-inscribing intimate constraints in new ways. When making any changes to high-support housing it is crucial that then tension between providing space for children and partners in state supported housing and the likely increased state scrutiny that accompanies such changes be at the forefront of the conversation. While child welfare is extremely important, the presence of a mental illness label and residence in highsupport housing must not, alone, justify greater state intervention to the intimate lives of residents. Changing this pathologization of, and limitation over, the reproductive lives of people with mental illness labels will require rethinking how social reproduction as a whole is organized. Part of this rethinking will require further research into how intimate limitation and control impact people with mental illness labels, not only in relation to socio-economic position and disability, but also in relation to gender, race, sexuality and citizenship status.

Received: 27 July 2017 Accepted: 27 November 2017 Published online: 19 December 2017

\section{Notes}

1 An exact count is not available (Suttor, 2016)

2 I verified this claim. These rights are confirmed on the Toronto Mental Health \& Addictions Supportive Housing Network website (n.d.)

3 "A landlord may give a tenant notice of termination of the tenancy if the number of persons occupying the rental unit on a continuing basis results in a contravention of health, safety or housing standards required by law. 2006,. 17, s. 67 (1)".'

4 There are some different regulations for rent-geared-to-income housing around occupancy but, to my knowledge, this does not apply to high-support housing. 


\section{References}

Arat-Koc S (2006) Whose social reproduction? Transnational motherhood and challenges to feminist political economy. In: Bezanson K, Luxton M (eds) Social reproduction: Feminist political economy challenges neoliberalism. McGill-Queen's University Press, Kingston \& Montreal, p 75-92

Bakker I (2003a) Neo-liberal governance and the reprivatisation of social reproduction: social provisioning and shifting gender orders. In: Bakker I, Gill S (eds) Power, production, and social reproduction: Human insecurity in the global political economy. Palgrave Macmillan, Basingstoke, p 66-82

Bakker I, Gill S (2003b) Global political economy and social reproduction. In: Bakker I, Gill S (eds) Power, production, and social reproduction: Human insecurity in the global political economy. Palgrave Macmillan, Basingstoke, $p$ 3-16

Bakker I, Gill S (2003c) Ontology, method and hypotheses. In: Bakker I, Gill S (eds) Power, production, and social reproduction: Human insecurity in the global political economy. Palgrave Macmillan, Basingstoke, p 17-41

Bezanson K, Luxton M (eds) (2006a) Social reproduction: Feminist political economy challenges neo-liberalism. McGill-Queen's University Press, Montreal

Bezanson K, Luxton M (2006b) Social reproduction and feminist political economy. In: Bezanson K K, Luxton M M (eds) Social reproduction: Feminist political economy challenges neo-liberalism. McGill-Queen's University Press, Montreal, p 3-11

Brodie J (2010) Globalization, Canadian family policy and the omissions of neoliberalism. North Carol Law Rev 88(5):1559-1592

Brown W (1992) Finding the man in the state. Fem Stud 18(1):7-34

Canadian Mortgage and Housing Corporation (CMHC) (2015) Rental market report: Ontario highlights, Ontario, Canada. https://www.cmhcchl.gc.ca/ odpub/esub/64507/64507_2015_B01.pdf. Accessed 19 July 2017

Capponi P (1992) Upstairs in the crazy house: The life of a psychiatric survivor. Viking Press, Toronto

Central LHIN (2012) Discretionary funding allocation process. http://www. centrallhin.on.ca/forhsps/policiesdirectivesresources.aspx. Accessed 25 July 2017

Centre for Addiction and Mental Health (CAMH) (2012) Road to recovery: Client experiences in supportive housing, Toronto, ON. https://www.camh.ca/en/ hospital/about_camh/influencing_public_policy/Documents/Road_to_ Recovery-Client_Experiences_in_Supportive_Housing.pdf. Accessed 18 July 2017

Chochinov HM, Frazee C (2016) Finding a balance: Canada's law on medical assistance in dying. Lancet 388(10044):543-545

Chouinard V, Crooks V (2005) Because they have all the power and I have none State restructuring of income and employment supports and disabled women's lives in Ontario, Canada. Disabil Soc 20(1):19-32

City Of Toronto Minutes (1983) Executive Committee Report Number 11.22. Mayor's Action Task Force on Discharged Psychiatric Patients, pp 1782-1785

City Of Toronto Minutes (1984) Executive Committee Report Number 11.1 Final Report of the Mayor's Action Task Force on Discharged Psychiatric Patients, pp 3479-3586

City of Toronto (n.d.) Toronto Municipal Code, Chapter 629: Property Standards, Section25. On file with author

Cohen BMZ (2013) The power of madness: A Marxist critique of social constructionism. In: Goodman, H, Russo, B \& Zózimo, J (eds) Beyond these walls: Confronting madness in society, literature and art, Interdisciplinary Press, Oxford, UK, pp 67-97. www.interdisciplinarypress.net/online-store/ ebooks/diversity-and-recognition/beyond-these-walls

Cohen BMZ (2016) Psychiatric hegemony: A Marxist theory of mental illness. Palgrave McMillian Press, London

Costa L, Voronka J, Landry D, Reid J, McFarlane B, Reville D, Church K (2012) Recovering our stories: A small act of resistance. Stud Social Justice 6 (1):85-101

Davis D (2009) The politics of reproduction: The troubling case of Nadya Suleman and assisted reproductive technology. Transform Anthropol 17(2):105-116

Davis L (2006) Constructing normalcy: The bell curve, the novel, and the invention of the disabled body in the nineteenth century. In: Davis L (ed) The disability studies reader.. Routledge, New York, p 3-16

Dickinson H (1993) Scientific parenthood: The mental hygiene movement and the reform of Canadian families, 1925-1950. Sci J Comp Fam Stud 24(3):387-402

Dwyer C (2017) Judge promises reduced jail time if tennessee inmates get vasectomies. NPR. http://www.npr.org/sections/thetwo-way/2017/07/21/ 538598008/judge-promises-reduced-jail-time-if-tennessee-inmates-get-vasectomies. Accessed 25 Sept 2017

Fudge J, Vosko L (2003) Gendered paradoxes and the rise of contingent work: Towards a transformative feminist political economy of the labour market. In: Clement W, Vosko L (eds) Changing Canada: Political Economy as Transformation.. McGill-Queen's University Press, Montreal and Kingston, $\mathrm{p}$ 183-209
Government of Ontario. Ontario providing faster access to mental health services for thousands of people. Newsroom. https://news.ontario.ca/mohltc/en/2017/ 02/ontario-providing-faster-access-to-mental-health-services-for-thousandsof-people. Accessed 25 Aug 2017

Gray C (1999) Will voters' response to health care reforms determine the fate of Mike Harris? Can Med Assoc J 160(11):1623-1624

Harvey D (2005) A brief history of neoliberalism.. Oxford University Press, New York

Housing Services Act Ontario (2011). https://www.ontario.ca/laws/statute/ 11h06\#BK60. Accessed 17 July 2017

Hubbard R (2006) Abortion and disability: Who should and should not inhabit the world? In: Davis L (ed) The disability studies reader.. Routledge, New York, p 93-103

Idee fixe records (n.d) Fiver: Audible Songs from Rockwood. http://ideefixerecords. com/if016.html. Accessed 10 July 2017

Ignagni E, Fudge Schormans A (2016) Reimagining parenting possibilities: Towards intimate justice. Stud Social Justice 10(2):238-260

Keil R (2002) 'Common-sense' neoliberalism: Progressive conservative urbanism in Toronto, Canada.Antipode 34(3):578-601

LaCroix, Marie. (1986) About a Boarding Home. Cuckoo's Nest. Sept \& Oct. CAMHA. Centre for Addition and Mental Health, Queen Street Site Fonds. Box 24-05, Series J-3

Laxer, K \& Armstrong, P (n.d.) Conceptual Guide to the Health and Social Care Module, Gender and Work Database, York University, Toronto, ON. http:// www.genderwork.ca/cpd/modules/health-social-care/. Accessed 17 July 2017

LeBaron G, Roberts A (2010) Toward a feminist political economy of capitalism and carcerality. Signs (Chic) 36(1):19-44

LeFrancois B, Menzies R, Reaume G (eds) (2013) Mad matters: A critical reader in Canadian mad studies. Canadian Scholars Inc. Press, Toronto

Local Health Integration Network Collaborative (LHINCollaborative) (2010) LHIN Priority Setting \& Decision Making Framework Toolkit, Ontario: Canada. http://www.lhincollaborative.ca/resources.aspx. Accessed 10 July 2017

Luxton M (2006) Feminist Political Economy in Canada and the Politics of Social Reproduction. In: Bezanson K, Luxton M (eds) Social reproduction: Feminis political economy challenges neoliberalism.. McGill-Queen's University Press, Kingston \& Montreal, p 11-44

Mallory J (1986) Rocket Launcher. Cuckoo's Nest. Sept \& Oct. CAMHA. Centre for Addition and Mental Health, Queen Street Site Fonds. Box 24-05, Series J-3

Marshall J (1982) Madness: An indictment of the mental health care system in Ontario. Brownstone Press, Toronto

Martel G (2016) For the Glory of the Nation: Eugenics, Child-saving and the Segregation of the "Feeble-Minded", Master's Thesis, School of Social Work: McMaster University, Hamilton, Ontario. https://macsphere.mcmaster.ca/ handle/11375/20540. Accessed 12 July 2017

McKeen W, Porter A (2003) Politics and transformations: Welfare state restructuring in Canada. In: Clement W, Vosko K (eds) Changing Canada: Political economy as transformation. McGill-Queen's University Press, Montreal, pp 109-144

Ministry of Community and Social Services. (n.d.) Ontario Disability Support Program Directive 2.2. http://www.mcss.gov.on.ca/en/mcss/programs/social/ directives/odsp/is/2_2_ODSP_ISDirectives. Accessed 25 Sept 2017

Ministries of Housing and Municipal Affairs (n.d.) Ontario's Long-Term Affordable Housing Strategy Update, Ontario, Canada. http://www.mah.gov.on.ca/ Page13782. Accessed 13 July 2017

Ministries of Housing and Municipal Affairs (2017) Ontario's Supportive Housing Policy Framework, Ontario, Canada. http://www.mah.gov.on.ca/Page15268. aspx. Accessed 13 July 2017

Ministry of Municipal Affairs and Housing (2014) Community Homelessness Prevention Initiative (CHPI) Guide to the Housing with Related Supports Service Category, Ontario, Canada. http://www.mah.gov.on.ca/AssetFactory aspx?did=12230. Accessed 17 July 2017

Moncrieff J (2008) Neoliberalism and biopsychiatry: A marriage of convenience. In: Cohen CI, Timimi S (eds) Liberatory psychiatry: Philosophy, politics, and mental health. Cambridge University Press, Cambridge, p 235-255

Morrow M (2004) Mental health reform, economic globalization and the practice of citizenship. Can J Community Ment Health 23(2):39-50

Morrow M (2017) 'Women and Madness' revisited: the promise of mad and intersectional frameworks. In Morrow M, Halinka Malcoe L (eds) Critical Inquiries For Social Justice in Mental Health. University of Toronto Press, Toronto, ON, p 33-59

Morrow M, Halinka Malcoe L (eds) (2017) Critical Inquiries For Social Justice in Mental Health. University of Toronto Press, Toronto, ON

Murray KB (2015) Bio-gentrification: Vulnerability biovalue chains in gentrifying neighbourhoods. Urban Geogr 36(2):277-299

Ontario Ministry of Children and Youth Services (2016) Ontario Family Risk Assessment Descriptors Neglect Index. Ontario Child protection tools manual (2016), pp 33-37. http://www.children.gov.on.ca/htdocs/English/ 
documents/childrensaid/Child-Protection-Tools-Manual-2016.pdf. Accessed 10 Sept 2017

Ontario Ministry of Health. (1993) Putting people first: The reform of mental health services in Ontario. http://ontario.cmha.ca/files/2011/06/puttingpeople first.pdf. Accessed 25 Sept 2017

Ontario Ministry of Health and Long-Term Care (2011) Open minds, healthy minds: Ontario's comprehensive mental health and addictions strategy, Ontario, Canada. http://www.health.gov.on.ca/en/common/ministry/public ations/reports/mental_health2011/mentalhealth_rep2011.pdf. Accessed 20 July 2017

Ontario Non-Profit Housing Association (ONPHA) (2016) 2016 waiting lists survey: ONPHA's final report on waiting lists statistics for Ontario. https:// www.onpha.on.ca/onpha/web/Policyandresearch/2016_Waiting_List_ Survey /Content/PolicyAndResearch/Waiting_Lists_2016/2016_Waiting_Lists_Surv ey.aspx?hkey=08cff4ce-7f97-4af4-910c-c64954d28a4a. Accessed 25 Sept 2017

Peck J, Tickell A (2002) Neoliberalizing space. Antipode 34(3):380-404

Property Standards ByLaws, Ottawa (n.d.), Ottawa, Ontario. http://documents. ottawa.ca/sites/documents.ottawa.ca/files/2013_416_en. Accessed 21 July 2017

Provincial Community Mental Health Committee (1988) Building Community Support for People: A Plan for Mental Health in Ontario. Ontario Ministry of Health, Toronto, ON, CAMHA. Centre for Addition and Mental Health, Queen Street Site Fonds. Box 23-01, Series J-3

Reaume G (2009) Remembrance of patients past: Patient life at the Toronto Hospital for the Insane, 1870-1940. University of Toronto Press, Toronto

Scott R (1987) Boarding house tragedy: Did John Dimun really die as the result of a "self-chosen, inappropriate lifestyle? Phoenix Rising 6(4):16-19

Residential Tenancies Act (2006). https://www.ontario.ca/laws/statute/06r17\#. Accessed 22 Sept 2017

Roberts D (1997) Killing the black body: Race, reproduction, and the meaning of liberty. Pantheon Books, New York, NY

Rossiter K, Clarkson A (2013) Opening Ontario's 'Saddest Chapter': A history of Huronia regional centre. Can J Disabil Stud 2(3):1-30

Russo J, Sweeney A (eds) (2016) Searching for a rose garden: Challenging psychiatry, fostering mad studies.. PCPS Books LTD, Monmouth, UK

Sanders T (2007) The politics of sexual citizenship: commercial sex and disability. Disabil Soc 22(5):439-455

Simmons H (1990) Unbalanced: Mental health policy in Ontario, 1930-1989. Wall \& Thompson, Toronto

Smith AM (2010) Neo-eugenics: A feminist critique of Agamben. Occas: Interdiscip Stud Humanit 1(2):1-12

Social Justice Tribunals of Ontario. (n.d.) Occupants and Roommates. Landlords, Tenants, Occupants and Residential Tenancies Interpretation Guideline 21. http://www.sjto.gov.on.ca/documents/ltb/Interpretation\%20Guidelines/21\% 20-\%20Landlords\%20Tenants\%20Occupants\%20and\%20Residential\% 20Tenancies. Accessed 25 Sept 2017

Statistics Canada (n.d) Table 115-006. Labour force status for adults with disabilities, by disability type and global severity, sex and age group, Canada, provinces and territories. http://www5.statcan.gc.ca/cansim/pick-choisir?lan$\mathrm{g}=$ eng\&p2=33\&id=. Accessed 3 Jan 2017

Statistics Canada (2011) National Housing Survey, Catalogue number 99014X2011027. http://www12.statcan.gc.ca/nhs-enm/2011/dp-pd/dt-td/ Index-eng.cfm. Accessed 26 July 2017

Steans J, Tepe D (2010) Introduction: Social reproduction in international political economy: Theoretical insights and international, transnational and local sitings. Rev Int Polit Econ 17(5):807-815

Stote K (2015) An act of genocide: Colonialism and the sterilization of Aboriginal women. Fernwood Publishing, Halifax, NS

Suttor G (2016) Taking Stock of Supportive Housing for Mental Health and Addictions in Ontario. Wellesley Institute, Toronto, ON, http://www.welles leyinstitute.com/publications/taking-stock-of-supportive-housing-for-mental -health-and-addictions-in-. Accessed 4 Jan 2017
Toronto Mental Health \& Addictions Supportive Housing Network (n.d) http:// www.tosupportivehousing.ca/about/supportive-. Accessed 3 July 2017

Tronto J (1993) Care. Moral boundaries: A political argument for an ethic of care. Routledge, New York, NY, pp 101-124

Vosko L (2002) The past, present (and futures) of feminist political economy in Canada: Reviving the debate. Stud Polit Econ 68:55-83

Vosko L (2006) Crisis tendencies in social reproduction: The case of Ontario's early years plan. In: Bezanson K, Luxton M (eds) Social reproduction: Feminist political economy challenges neoliberalism. McGill-Queen's University Press, Kingston \& Montreal, p 145-172

Vosko L (2010) Managing the margins: Gender, citizenship, and the international regulation of precarious employment. Oxford University Press, Oxford

Wacquant L (2010) Crafting the neoliberal state: Workfare, prisonfare and social insecurity. Sociol Forum 25(2):197-220

Warner, A (n.d.) First play and track-by-track guide: Fiver, audible songs from Rockwood CBC: Music. http://www.cbcmusic.ca/first-plays/277/first-playand-track-by-track-fiver-audible-. Accessed 5 June 2017

Wiktorowicz ME (2005) Restructuring mental health policy in Ontario: Deconstructing the evolving welfare state. Can Public Adm 48(3):386-412

Wilton R (2004) More responsibility, less control: Psychiatric survivors and welfare state restructuring. Disabil Soc 19(4):371-385

\section{Data availability}

The datasets generated during and/or analysed during the current study are not publicly available due to the highly sensitive nature of the data gathered and the confidentiality promised to the interview participants but are available from the corresponding author on reasonable request.

\section{Acknowledgements}

The author would like to thank Greg Bowley, Kim Collins, and the two anonymous peerreviewers for their generous feedback.

\section{Additional information}

Competing interests The author declares no competing financial interests.

Reprints and permission information is available online at http://www.nature.com/ reprints

Publisher's note: Springer Nature remains neutral with regard to jurisdictional claims in published maps and institutional affiliations.

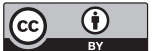

Open Access This article is licensed under a Creative Commons Attribution 4.0 International License, which permits use, sharing, adaptation, distribution and reproduction in any medium or format, as long as you give appropriate credit to the original author(s) and the source, provide a link to the Creative Commons license, and indicate if changes were made. The images or other third party material in this article are included in the article's Creative Commons license, unless indicated otherwise in a credit line to the material. If material is not included in the article's Creative Commons license and your intended use is not permitted by statutory regulation or exceeds the permitted use, you will need to obtain permission directly from the copyright holder. To view a copy of this license, visit http://creativecommons.org/ licenses/by/4.0/.

(C) The Author(s) 2017 